\title{
The effect of chronic stress on the testis of adult albino Rats and the possible protective effect of astaxanthin supplementation (Histological, immunohistochemical and biochemical studies)
}

\author{
Original \\ Article \\ Maha Zayed Mohammed', Karima fawzy abd elfadeel', \\ Heba Mohamed Abdel-Aziz', Aml Fawzy and Walaa Samy
}

${ }^{1}$ Department of Histology Faculty of Medicine, Zagazig University, Egypt

${ }^{2}$ Department of Biochemistry, Faculty of Medicine, Zagazig University, Egypt

\begin{abstract}
Background and Objectives: Stress can disrupt homeostasic balance within the organisms. Chronic stress can have damaging effects on the whole organism. The present study aimed to throw more light on themolecular,immunological and histological alterations in adult albino rat's testis subjected to chronic stress and to demonstrate whether the potential chronic stress-induced testicular alterations could be ameliorated by astaxanthin or not.

Materials and Methods: Forty healthy adult male albino rats were used in this study, they were assigned as 3 main groups: Group I (Control group) which are subdivided into two equal groups, Group II (stress group) rats were restrained for $1 \mathrm{~h}$ and after 4 hs they are forced to swim for 15 minutes every day for 6 months, and Group III (protective group) rats were subjected to stressors as previous group in concomitant with daily administration of astaxanthin $(25 \mathrm{mg} / \mathrm{kg}$ b.w.) dissolved in $1 \mathrm{ml} \mathrm{normal}$ saline in a single daily doseorally in a single daily dose. Blood samples and testicular tissues were collected and assayed for histological, immunohistochemical and biochemical changes.

Results: The results of the present study demon $\neg$ strated thatthere were degenerative changes in spermatogenic and Sertoli cells of stress group and were associated with statistical significant reduction in height of germinal epithelium, Ki-67 and vimentinimmunoexpression. These changes were observed to be reduced in astaxanthin protected group.Also,there was a decrease in serum testosterone levels in stress group, which were normalized after astaxanthin administration. Also, stress significantly increased the serum levels of malondialdehyde, and decreased levels of total antioxidant capacity TAC.

Conclusions: This study concluded that astaxanthin has beneficial protective effects against the deleterious effects of chronic stress on the testis. Therefore, it may be a suitable nutrional supplement in alleviating some negative aspects of chronic stress effects on testis.
\end{abstract}

Key Words: Astaxanthin, ki-67, sertoli cell, stress, vimentin.

Revised: 17 February 2019, Accepted: 18 February 2019

Corresponding Author: Maha Zayed Mohammed, Department of Histology Faculty of Medicine, Zagazig University, Egypt, Tel.: +20 1090886200, E-mail: mahazayed72@yahoo.com.

ISSN: 1110-0559, Vol. , No.

\section{INTRODUCTION}

Stress is a general adaptive response activated by stimuli that disrupt homeostatic balance within the organisms ${ }^{[1]}$. These stimuli are designated as stressors and the response to them depends on their intensity, unpredictability and uncontrollability ${ }^{[2]}$.

Physical or psychological stressors result in stress response. Psychological stressors are stimuli that affect emotion resulting in fear or frustration ${ }^{[3]}$. On the other hand, physical stressors disturb the internal or external environment of an organism as anoxia, cold or physical strain (exercise or injury) ${ }^{[1]}$.

Stress researches can be divided into research examining the effects of acute or chronic stress $^{[1]}$. Acute stress becomes harmful if it persists chronically ${ }^{[3]}$. Chronic stress worsens the physical health as cardiovascular disorders ${ }^{[4]}$.

The main systems activated by the stress are the hypothalamic-pituitary-adrenal (HPA) axis and the sympathetic adrenomedullary (SAM) system ${ }^{[5]}$. Stress leads to release of corticotropin-releasing hormone $(\mathrm{CRH})$ from the paraventricular nucleus, which causes the release of adrenocorticotropic hormone $(\mathrm{ACTH})$ that acts on the adrenal cortex to synthesize and secrete the glucocorticoid (GC) hormone; cortisol (in humans) or corticosterone (in rodents) ${ }^{[1]}$. The hypothalamus also activates the adrenal medulla via the sympathetic nervous system (SNS), resulting in the release of the catecholamines; epinephrine and norepinephrine. $\mathrm{ACTH}, \mathrm{CRH}$, and GCs provide the negative feedback necessary to diminish the stress respons $\mathrm{e}^{[6]}$. 
Ki-67 expression is one of the markers for cell proliferation. Its high expression has been reported in cells during G2 and early M stages of cell growth. In fact the Ki-67 protein is present during all active phases of the cell cycle $\mathrm{G}^{[1]}, \mathrm{S}, \mathrm{G}^{[2]}$, and mitosis but is absent from resting cells or in $\mathrm{G}(0)^{[7,8]}$.

Stressful conditions lead to excessive production of free radicals which cause an imbalance in the oxidant/ antioxidant system ${ }^{[9]}$. Testicular tissues are rich in polyunsaturated fatty acid content and poor in antioxidant defense so, they are prone to be attacked by reactive oxygen species (ROS) which are capable of oxidizing proteins, lipids, and deoxyribonucleic acid (DNA) leading to cellular damage ${ }^{[10]}$.

Astaxanthin (AST) is a red-pigment carotenoid occurring naturally in a wide variety of living organisms and classified as xanthophylls. It has a chemical structure similar to $\beta$-carotene with high nutritional and medicinal values. In the 1930s, AST was separated from shrimp and crab shells; however, its physiological function did not meet attention until the $1980 \mathrm{~s}^{[11]}$.

Astaxanthin has many highly potent pharmacological effects, including antioxidant, anti-tumor, anti-cancer, anti-diabetic and antiinflammatory properties. The antioxidant activities are via its ability to inhibit nitric oxide production and inflammatory gene expression ${ }^{[12,13,14]}$.

Despite many reports study the influence of stress stimuli on the testes, one important point has not been addressed, which is whetherrecovery from testicular damage after exposure to stress stimuli is possible.

Thus, the objective of the present study was to evaluate theeffect of chronic stress on testicular tissues of adult rats and to investigate the possible protective role of astaxanthin.

\section{MATERIALS AND METHODS}

\section{Materials}

\section{Chemicals:}

Astaxanthin(AST) (cat\# 4727-61- ), Synonym: (3 S, 3'S ) - 3, 3'-Dihydroxy- $\beta, \beta$-Carotene- $4,4^{\prime}$ dione, 3,3 '-Dihydroxy- $\beta$-carotene- 4,4 '-dione, transAstaxanthin) was obtained from (Sigma-Aldrich, Steinheim, Germany) in the form of pink to very dark purple powder with the following properties: HPLC $: \geq 97 \%$ - body weight; 596,8-storage temperature; $-20^{\circ} \mathrm{C}$-Light and air sensitive and packages: $50 \mathrm{mg}$ in glass bottle.

\section{Stressors:}

Two kinds of stressors were used byNirupama and Yajurvedi ${ }^{[15]}$, restraint, wherein rats were placed in an open-ended cylindrical restrainer $(6.7 \mathrm{~cm}$ in diameter and $22.2 \mathrm{~cm}$ in length) for $1 \mathrm{~h}$ per episode followed by forced swimming, wherein rats were individually forced to swim for 15 minutes per episode in a glass jar (18 inches height $\times 8.75$ inches outer diameter) filled two thirds full of water at a temperature of $272 \pm^{\circ} \mathrm{C}$.

\section{Animals}

Forty healthy adult male albino rats (35- months) weighing 180200- $\mathrm{g}$ were used in this study. They were purchased from the center of experimental animals, Faculty of Veterinary medicine, Zagazig University. They were housed under standard laboratory conditions at a temperature $\left(23 \pm 2{ }^{\circ} \mathrm{C}\right)$, humidity $(54 \pm 5 \%)$. They fed ad libitum and allowed for free water supply throughout the period of the experiment. All experimental procedures were approved and carried out in accordance with the guidelines of the Institutional Animal Care and Use Committee accepted by Faculty of Medicine, Zagazig University,Zagazig, Egypt.

Experimental design:

Three groups of albino rats were assigned:

Group I (Control group): subdivided into two equal subgroups (10 rats in each):

Subgroup Ia (Negative control group): Were kept without any intervention.

Subgroup Ib (Positive control group): Were treated with astaxanthin with a dose of $25 \mathrm{mg} / \mathrm{kg} \mathrm{b.w}$ according to Akca et al. ${ }^{[16]}$ dissolved in $1 \mathrm{ml}$ normal saline orally in a single daily dose for 6 months.

Group II (stress group): Ten rats were restrained for $1 \mathrm{~h}$ and after a gap of $4 \mathrm{hs}$ they are forced to swim for 15 minutes every day for 6 months $^{[17]}$. The sequence of stressors and timing of the exposure were randomly changed every day to minimize habituation.

Group III (protective group): Ten rats were subjected to stressors as previously mentioned for 6 months in concomitant with daily oral administration ofastaxanthin $(25 \mathrm{mg} / \mathrm{kg} \quad$ b.w.) dissolved in $1 \mathrm{ml}$ normal saline in a single daily dose ${ }^{[16]}$.

At the end of experiment,blood samples were drawn by heart puncture; the testes were removed 
and weighed. Right testicular tissues were kept in liquid nitrogen at $-80^{\circ} \mathrm{C}$ in deep freezer for ribonucleic acid (RNA) extraction and the left one was kept in 10\% phosphate buffered formalin for histopathological and immunohistochemical study. The epidydimis was used for determining total sperm count and motility.

\section{Methods:}

Histological studies: The animals of all groups were anaesthetized by ether and then left testes were dissected and their capsules were opened carefully and immersed in fixative $10 \%$ formol-salinefor 10 minutes, until testicular tissue slightly hardened

Light microscope technique:Testicular samples were cut in small pieces $(1 \mathrm{~cm} 2)$ size and fixedin $10 \%$ formol-saline and processed to prepare paraffin blocks. Sections of $5-\mu \mathrm{m}$ thickness were cut and stained with Hematoxylin and eosin (H\&E) stains according to Bancroft and Layton ${ }^{[18]}$. Immunohistochemical procedure was carried out using an avidin- biotin-peroxidase complex technique to detect $\mathrm{Ki}-67$ protein which is a marker for cell proliferation and vimentin, an intermediate filament protein in Sertoli cells of testis. The deparaffinized sections (4- $\mu \mathrm{m}$ thickness) were incubated in $0.3 \%$ hydrogen peroxide for $30 \mathrm{~min}$ to block the endogenous peroxidase. After rinsing with phosphate buffer saline (PBS), the testicular sections were incubated with the following primary anti $\neg$ bodies for $30 \mathrm{~min}$ at room temperature: Anti- Ki67 (sc 7846; Dako, Glostrup, Denmark) at dilutions of 1:1,000. Anti-vimentin mouse monoclonal antibodies in dilution of 1: 400 (Cat.\# M7020, Dako).the slides then were washed with PBS and incubated with the secondary anti-mouse antibodies universal kits obtained from Zymed Corporation. They were then incubated with substrate chromogen DAB (3,3diaminobenzidine) for 13- minutes which resulted in brown-colored precipitate at the antigen sites and Mayer's hematoxylin was used as a counter stain. Negative control sections were prepared using PBS without using the primary antibody ${ }^{[19]}$. Sections were viewed using an Olympus microscope (C5060-AUD, 5H01155 JAPAN) and images were captured by a digital camera (Canon PowerShot A620, England, UK). The scale bar was added to the photomicrographs according calibration sheet using power point (https://www.youtube.com/ watchv=3 bynnPQQxmg).

Transmission electron microscope technique:Testicular samples were cut in small pieces of $1 \mathrm{~mm} 2$ size and fixed in $2.5 \%$ glutaraldehyde for 24 hours. Specimens were washed in $0.1 \mathrm{M}$ phosphate buffer at $4^{\circ} \mathrm{c}$, then post fixed in $1 \%$ osmium tetroxide at room temperature. Specimens were dehydrated in ascending grades of ethyl alcohol then embedded in epoxy resin. Semithin sections $(1 \mu \mathrm{m})$ were stained with toluidine blue in borax and examined with light microscope. Ultrathin sections $(50 \mathrm{~nm})$ were cut, mounted on copper grids and stained with uranyl acetate and lead citrate ${ }^{[20]}$. Specimens were examined and photographed with JEM 1200 EXII transmission electron microscope in Faculty of agriculture, Mansoura University

Morphometric study: The height of germinal epithelium was measured using $\mathrm{H} \& \mathrm{E}$ stained sections from photos of X 200 magnification by Digimizer 4.3.2 (MedCalc Software bvba, Belgium) from randomly selected three different fields/rat of each group. From anti-BK-67 and antivimentinimmunohistochemically stained sections, the areas of positive nuclear Ki-67 and cytoplasmic vimentinimmunoexpressions, respectively, were done within 6 fields for each rat at a total magnification $X$ 400 using image analysis software (National Institute of Health; NIH, Bethesda, MD, USA $)^{[21]}$.

In each chosen field the germinal epithelium lining the seminiferous tubules were enclosed inside the standard measuring frame. The positively reactive areas were masked by a red binary color to be measured and the total area (in \%) of positive immunoreactions in each photo was measured and the mean values for each group were obtained.

\section{Percentage Body weight gain and relative testicular weights:}

Percentage body weight: using a weighing scale, the animals were measured before study initationto determine the initial weights and weekly for 16 weeks todetect the percentage of weight gain ${ }^{[22]}$.

Relative testicular weights: were determined by dissecting both testes and then weight them to obtain the absolute weight. The relative testicular weight was calculated in percentage of average absolute testicular weight/ body weight ${ }^{[23]}$.

\section{Biochemical assay:}

Hormonal analysis: Blood samples were prepared to measure serum testosterone level which estimated by enzyme linked immunosorbent assay kit, and supplied by DRG International, Inc.USA. Following instruction of the manufacturer and expressed as $\mathrm{ng} / \mathrm{ml}^{[24]}$.

Evaluation of sperm parameters: The cauda epididymis was excised, crushed and incubated in a pre-warmed Petri dish containing $10 \mathrm{ml}$ Ringer solution at $37^{\circ} \mathrm{C}$. The spermatozoa were allowed to 
disperse into the medium. After $20 \mathrm{~min}$, the cauda epididymis was detached, and the suspension was gently shaken (Fig. A)to homogenize for:

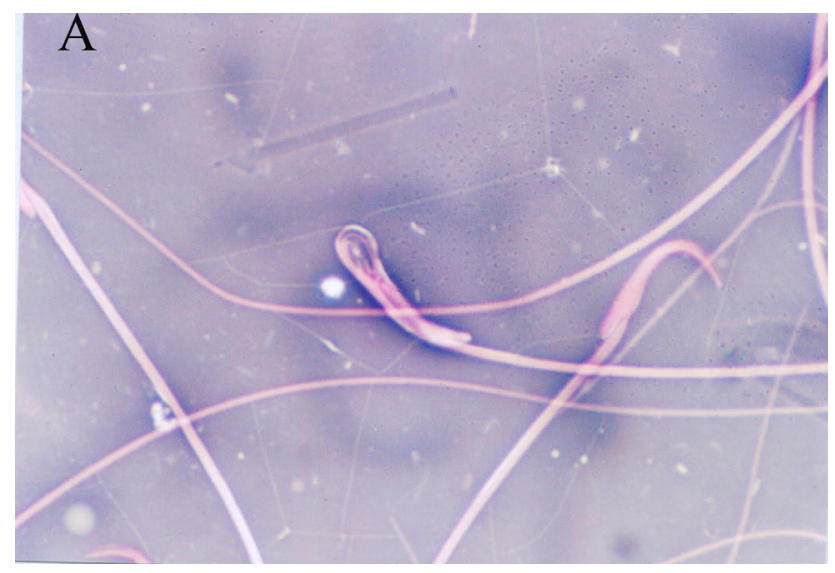

Fig. A: A photomicrograph of a sperms with heads and tails obtained from the semen of an adult male albino rat. $\quad$ (Nigrocin\&Eosin $\times 400)$

Sperm count: $15 \mu \mathrm{L}$ of the diluted sperm suspension was transferred to each counting chamber of the hemocytometer and allowed to stand for 5 min. The cells which settled during this time were counted under light microscope at a magnification of $\times 400(25)$.

Sperm motility: The spermatozoa were classified into motile or immotile. The motility assay was conducted by observing a small aliquot $(20 \mu \mathrm{L})$ of sperm suspension on a slide glass at $37^{\circ} \mathrm{C}$. The percentage of motile spermatozoa was determined by counting more than 200 spermatozoa randomly in 10 selected fields under a light microscope (Olympus BX51,Germany), and the mean number of motile spermatozoa that showed progressive forward movement $\times 100 /$ total number of spermatozoa was calculated ${ }^{[26]}$.

Assessment of total antioxidant capacity (TAC) and malondialdehyde (MDA): 0.30.4- gram of the right testicular tissue was homogenized in ice-cold $\mathrm{KCL}(150 \mathrm{mM})$ and then the mixture was centrifuged at $3000 \mathrm{~g}$ for $10 \mathrm{~min}$. The supernatants were used for evaluating TAC and MDA. For estimation of total antioxidant capacity, ab65329 Total Antioxidant Capacity Assay Kit (Colorimetric) was used. The lipid peroxidation rate, MDA content of the collected testis samples was determinedspectrophotometricall yusing (MDA) Assay Kit.

\section{Statistical analysis:}

All data were expressed as mean \pm SD. Statistical analysis was performed using the Statistical Package for the Social Sciences (SPSS) software, version 13.00 (Chicago, Illinois, USA). Statistical significance was determined by one-way analysis of variance for differences between the means of different groups. Further analysis was carried out using the post-hoc test to compare the parameters between the different groups with each other. Probability of $\mathrm{P}$ value less than 0.05 was considered statistically significant.

\section{RESULTS}

\section{I- Light and electron microscope results}

Light microscopic examination of testis sections from control group revealed that the testicular parenchymas were composed of packed seminiferous tubules. The interstitiuminbetween the tubules were relatively narrow(Fig. 1A). The seminiferous tubules were lined by stratified germinal epithelium formed of several types of spermatogenic cells; spermatogonia, primary spermatocytes, spermatids and supporting Sertoli cells. The spermatogonia appeared small rounded cells with rounded nuclei and primary spermatocytes appeared larger in size with rounded dark nuclei. Spermatids were small rounded cells with pale nuclei and there were flagella of sperms in the lumina of the tubules (Fig. 1B).

Electron microscopic resultsof testis sections from control group revealed thatSpermatogonia appeared with euchromatic nuclei. The primary spermatocytes showed large rounded nuclei with synaptonemal complex which appeared as densely packed particulate nucleoplasm with some electron dense clumps of irregular shapes. Regarding Sertoli cells, they showed large euchromatic nuclei and prominent nucleoli. Their cytoplasm contained mitochondria. They rested on a regular basement membrane. Myoid cells with flattened nuclei were seen within the basement membrane (Figs. 2A\&B). The spermatids of the same group showed rounded euchromatic nuclei and acrosomal cap on one side of the nucleus. Early stage of spermatid showed acrosomal granule. Their cytoplasm contained peripherally arranged mitochondria (Fig. 2C).The cross sections in the mid, principal and end pieces of the sperms showed a central axoneme formed of nine doublets of microtubules with two central singlets. In the mid pieces, the axoneme was surrounded by nine outer dense fibers, mitochondrial sheath and cell membrane. In the principal pieces, it was surrounded by seven outer dense fibers and was enclosed by fibrous sheaths. Terminal end pieces were formed of axoneme surrounded by cell membrane (Fig. 2D). The Leydig cells of control group showed ovoid euchromatic nuclei with thin rim of heterochromatin beneath the nuclear membrane. Their cytoplasm contained lipid droplets and mitochondria (Fig. 2E). 
Light microscopic examination of testis sections from stress group revealed that the testicular parenchymas were composed of distorted seminiferous tubules. The interstitiuminbetween them was wideand contained congested blood vessels and homogenous acidophilic materials (Fig. $3 \mathrm{~A}$ ). Some seminiferous tubules were lined by cells exhibited darkly stained nucleiand vacuolated cytoplasm with marked separation between their germinal cells. Their lumen revealed exfoliated cells and the interstitium contained homogenous acidophilic materials (Fig.3B).

Electron microscopic resultsof testis sections from stress groupshowed some spermatogenic cells with nuclei had disintegrated chromatins and the cytoplasm around them contained lysosomes, multiple electron dense bodies with variable sizes, dilated SER and elongated mitochondria (Figs. $4 A \& B$ ). Stress group revealed that some spermatids appeared with shrunken nuclei (Fig. 4C).On the other hand, most cross sections of sperms of the same group appeared deformed and degenerated and some sections showed vacuolated mitochondria within mitochondrial sheath of middle piece. However, some sperms have a normal structure with wellorganized axoneme and fibrous sheath (Fig. 4D). Aggregation of nuclear chromatin within apoptotic Leydig cell nuclei were observed in Stress group. Also, cytoplasm of these cells contained abundant dilated cisternae of smooth endoplasmic reticulum (Fig. 4E)

Light microscopic examination of testis sections from protected group showed that most seminiferous tubules had nearly regular contour similar to those of the control group. Their epithelial lining exhibited multinucleated giant cells. The interstitiuminbetween the tubule was wide and contained congested blood vessels (Fig. 5A). The germinal epithelium of some tubules revealed wide intercellular spaces between spermatogenic cells. The interstitium contained homogenous acidophilic material (Fig. 5B ).

Electron microscopic resultsof testis sections from protected grouprevealed that primary spermatocytes and Sertoli cells exhibited their normal fine structure. Primary spermatocytes appeared with large rounded nuclei with synaptonemal complex. Sertoli cells showed large euchromatic nuclei with prominent nucleoli. However, some electron dense bodies were seen deposited within cytoplasm of Sertoli cells. They were resting on an irregular basement membrane (Fig. 6A).The group revealed that spermatids had large euchromatic nuclei and their cytoplasm contained peripherally arranged mitochondria (Fig. 6B). In Protective group sections also most transverse sections of sperms exhibited their normal structure with well organizedaxoneme and fibrous sheath. However, few sperms appeared deformed and degenerated (Fig. 6C). Moreover, Leydig cells of the protective group showed irregular euchromatic nuclei with coarse clumps of peripheral heterochromatin. Their cytoplasm contained lipid droplets and mitochondria (Fig.6D).

Light microscopic examination of immunohistochemically stained testis sections showed Ki-67 nuclear immunoreactivity which was strong and numerous in the spermatogenic cells of both control groups (Figs.7A\&B).In stress group, immunoreactivity to Ki-67 in few spermatogenic cells (Fig. 7C) while in protective group, there were a moderate nuclear immunoreactivity to the same proteins (Fig.7D). As regarding Vimentinimmunostaining,the control groups showed positive vimentinimmunostaining in the midportion and apices of Sertoli cell walls and their adjoining germ cells and spermatozoa(Figs.7E\&F).Meanwhile, the stress group,vimentin immunoreaction was seen as streaks in the midportion of Sertoli cells in the contact areas between them and spermatocytes (Fig.7G). Protective group revealed distribution of vimentinimmunostaining in the midportion of some Sertoli cells and others in apices of them (Fig.7H).

\section{II-Morphometric and statistical results:}

Percentage Body weight gain and relative testicular weights:

Statistical analysis of the results showed a significant decrease in the percentage of body weight gain and relative testicular weights in stress group when compared with both control and protective groups $(\mathrm{P} \leq 0.05)$. Moreover, there was no significant difference in the same parameters between control and protective groups $(\mathrm{P} \geq 0.05)$ (Table 1$)$.

\section{Serum testosterone concentration:}

Statistical analysis of the results showed a significant decrease in the serum testosterone concentration in stress group, when compared with both control and protective groups $(\mathrm{P} \leq 0.05)$. Moreover, there was no significant difference inthe same parameter between both control and protective groups ( $\mathrm{P} \geq 0.05$ ) (Table 2).

\section{Sperm parameters:}

There was a significant decrease in the total sperm count and percentage of motile spermatozoa and a significant increase in immotile spermatozoa in stressed group compared to respective control and protective groups $(\mathrm{P} \leq 0.05)$. Moreover, there was 
no significant difference in these parameters of both control and protective groups (III) $(\mathrm{P} \geq 0.05)$ (Table 2).

\section{The main diagonal diameter of seminiferous tubules}

Statistical analysis of the results showed a significant decrease in the main diagonal diameter of seminiferous tubules in stress group when compared with both control and protective groups $(\mathrm{P} \leq 0.05)$. Moreover, there was no significant difference in the same parameter between both control and protective groups ( $\mathrm{P} \geq 0.05)$ (Table 3$)$.

\section{The height of germinal epithelium}

Statistical analysis of the results showed a significant decrease in the main thickness of testicular epithelium in stress group when compared with both control and protective groups $(\mathrm{P} \leq 0.05)$. Moreover, there was no significant difference in the same parameter between of both control and protective groups $(\mathrm{P} \geq 0.05)$ (Table 3$)$.

\section{Area $\%$ of Ki-67 Results}

Statistical analysis of the results showed a significant decrease in area $\%$ ofKi- 67 of stress group when compared with both control and protective groups $(\mathrm{P} \leq 0.05)$. Moreover, there was no significant difference in the same parameter between the control and protective groups $(\mathrm{P} \geq 0.05)$ (Table 3$)$.

\section{Area \% of Vimentin Results}

Statistical analysis of the results showed a significant decrease in area \% ofVimentinof stress group when compared with both control and protective groups $(\mathrm{P} \leq 0.05)$. Moreover, there was no significant difference in the same parameter between control and protective groups $(\mathrm{P} \geq 0.05)$ (Table 3).

\section{Biochemical results:}

\section{Testicular totalantioxidantcapacity (TAC) and} malondialdehyde(MDA):

The current results revealed that MDA increased significantly $(\mathrm{P}<0.05)$ in stress group compared to control group. Administration ofastaxanthinnormalized in protective group, the increase MDA activity observed in stress group. In stress group, TAC was decreased significantly compared to control group $(\mathrm{P}<0.05)$. For protective group, there was a significant increase in TAC activity when compared to stress groupand there was no significant difference between both control and protective groups $(\mathrm{P} \geq 0.05)$ (Table4 ).

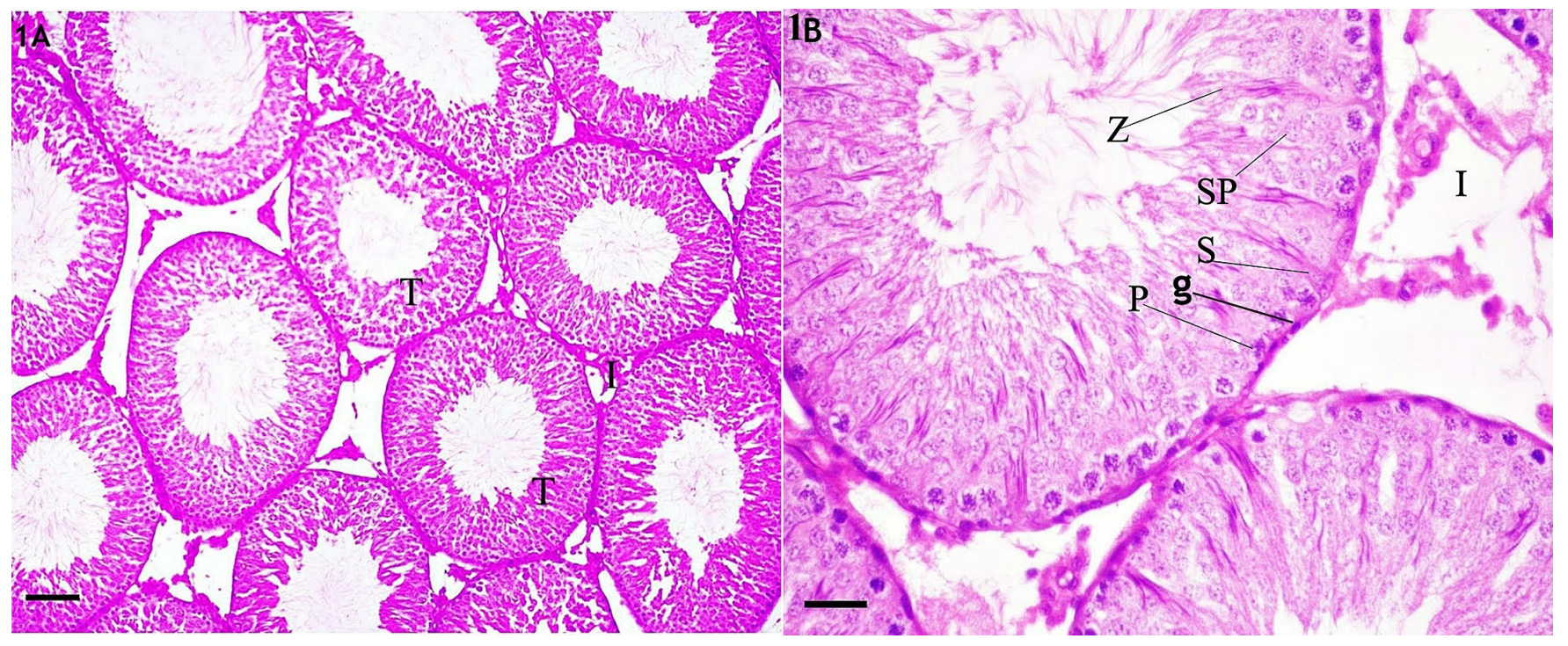

Fig. 1: A photomicrograph of a section in the testis ofcontrolgroupin adult albino rat: (1A): Showing that testicular parenchyma consists of packed seminiferous tubules (T) and narrow interstitiuminbetween (I). (H\&E $\times 10$, scale bar $100 \mu \mathrm{m})$. (1B): Showing the seminiferous tubule is lined by spermatogonia (g), primary spermatocytes (P), spermatids (SP) and supporting Sertoli cells (S). The lumen of the tubule contains flagella of sperms (Z) and the interstitium (I) is also noticed $(\mathrm{H} \& \mathrm{E} \times 40$, scale bar $20 \mu \mathrm{m})$ 


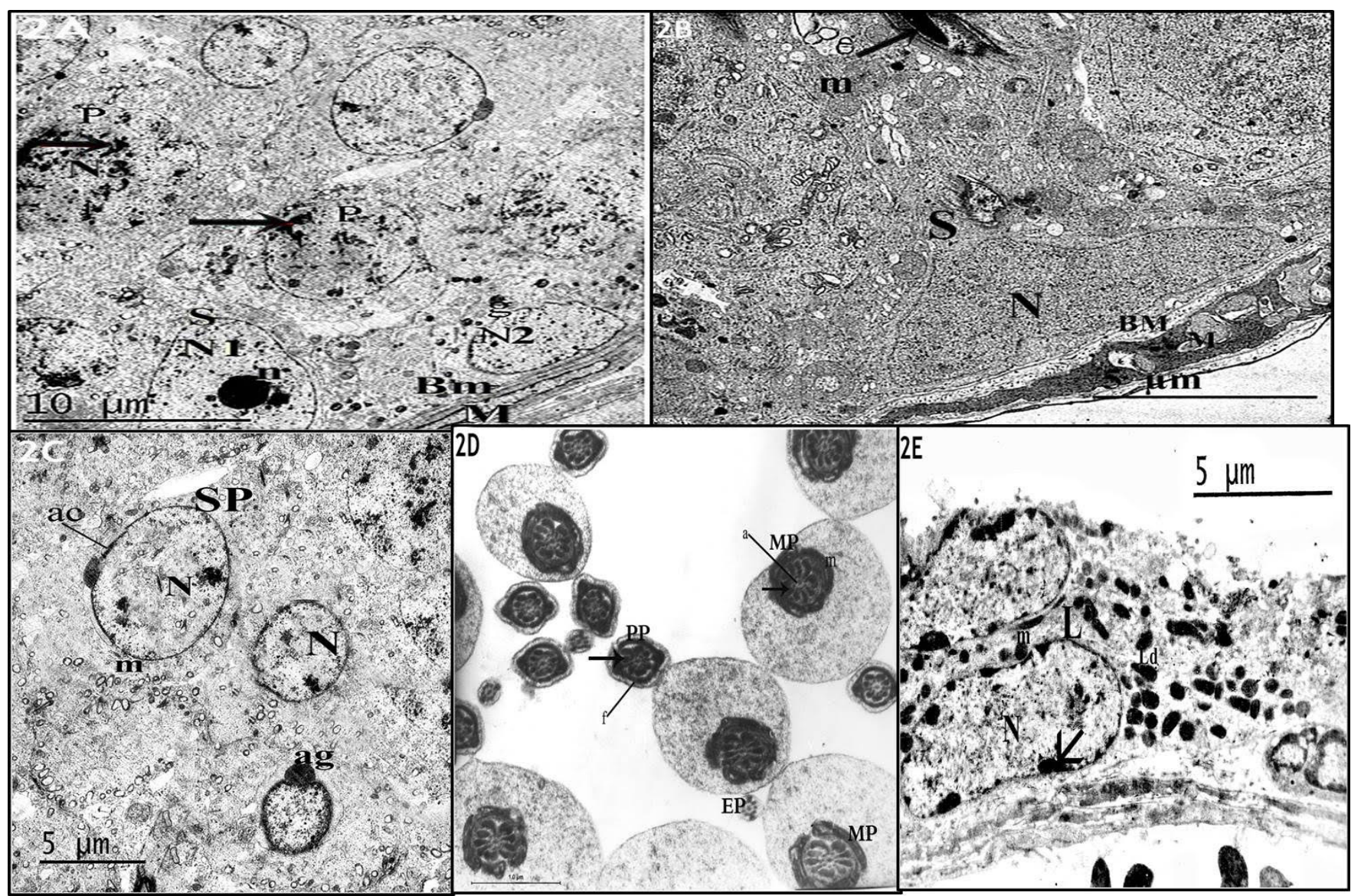

Fig. 2: Electron micrographs of ultrathin sections of albino rat's testis in control group showing: (2A): Showingaspermatogonium (g) and Sertoli cell (S). They rest on a regular basement membrane (Bm). Sertoli cell (S) appears with large euchromatic nucleus (N1) and prominent nucleolus (n). Spermatogonium (g) appears with euchromatic nucleus (N2). Primary spermatocyte (P) has large nucleus (N3) showing synaptonemal complex (arrow). Myoid cell (M) with flattened nucleus can be seen. (2B): Showing Sertoli cell (S) with large euchromatic nucleus (N) and its cytoplasm contains mitochondria (m). Head of sperm (arrow) can be seen inserted within its cytoplasm. Myoid cell (M) can be seen within the basement membrane (BM). (2C): Control group showing spermatids (SP) with rounded euchromatic nuclei (N) and acrosomal cap (ac) on one side of the nucleus. Their cytoplasm shows peripherally arranged mitochondria (m). Early stage of spermatid shows acrosomal granule (ag). (2D): Showing cross section in the middle piece of the sperms (MP) which consists of nine doublets of microtubules with two central singlets (axoneme) (a) surrounded by nine outer dense fibers (arrow), mitochondrial sheath (m) and cell membrane. Cross section in the principal piece (PP) is formed of axoneme surrounded by seven outer dense fibers (arrow) and enclosed by fibrous sheath (f). Terminal end piece (EP) is formed of axoneme surrounded by a cell membrane. (2E): Showing two Leydig cells (L) with ovoid euchromatic nuclei $(\mathrm{N})$ having thinrim of heterochromatin beneath the nuclear membrane (arrow). Their cytoplasm contains lipid droplets (Ld) and mitochondria (m).

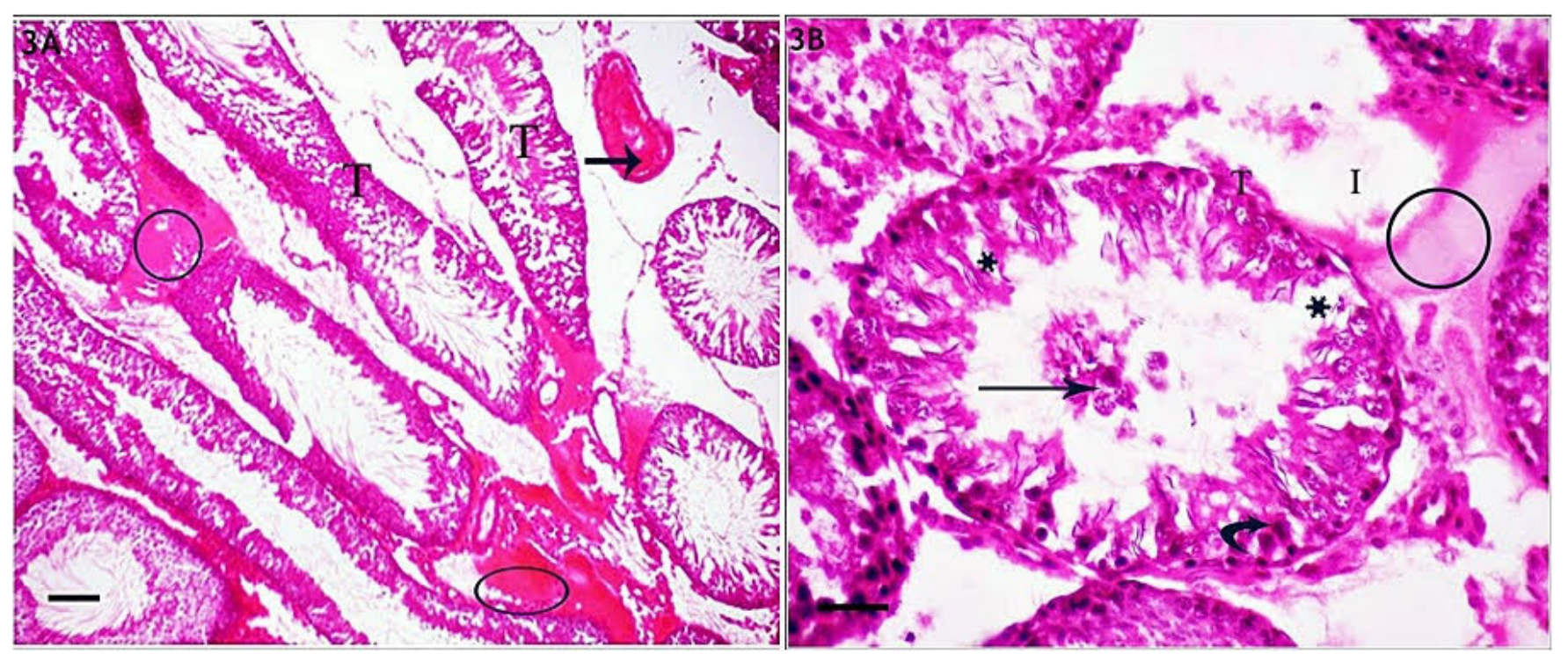

Fig. 3: A photomicrograph of a section in the testis ofstressgroup in adult albino rat: (3A): Showingdistorted seminiferous tubules (T). The interstitium (I) inbetweenthemis wide and contains congested blood vessels (arrow) and alsohomogenous acidophilic material (circles). (H\&E $\times 10$, scale bar 100 $\mu \mathrm{m})$. (3B): Showingdistorted seminiferous tubule (T). It is lined by germinal cellswith darkly stained cytoplasm and nuclei (curved arrow) with marked separation inbetweenthem (stars). Itslumen reveals exfoliated cells (arrow) and the interstitium (I) contains homogenous acidophilic material (circle). (H\&E $\times 40$, scale bar $20 \mu \mathrm{m})$ 


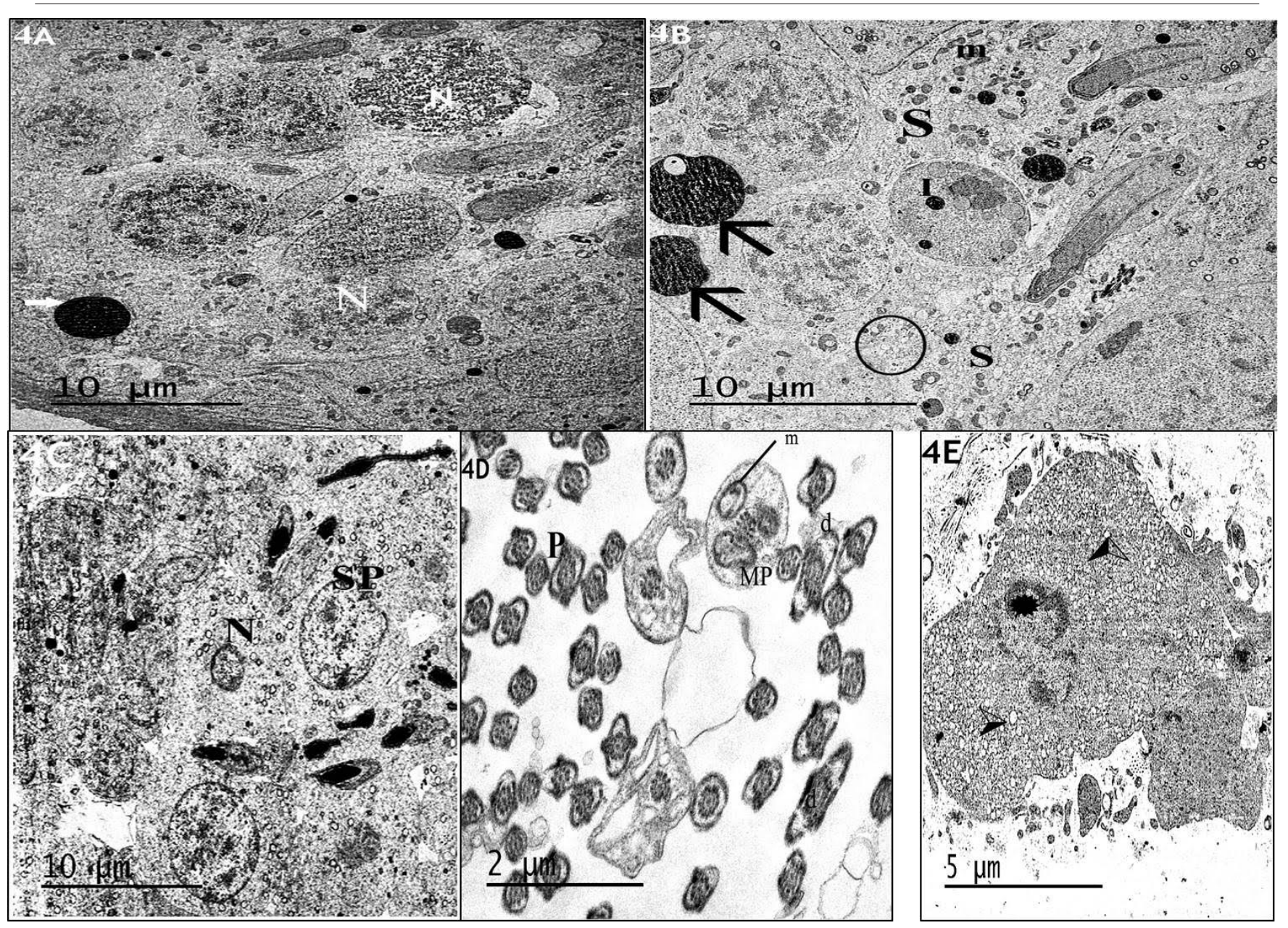

Fig. 4: Electron micrographs of ultrathin sections of albino rat's testis in stress group showing: (4A): Showingspermatogenic cells with nuclei have disintegrated chromatin (N). The cytoplasm around them shows deposition of electron dense materials (thick white arrow). (4B): ShowingSertoli cell (S) process which contains lysosome (1), multiple electron dense bodies with variable sizes (arrow), dilated SER (circle) and elongated mitochondria (m). (4C): Stress group showing many spermatids (SP). Some of them have shrunken nuclei (N). (4D): Stress group showing that some cross sections of sperms have a normal structure $(\mathrm{P})$ with well organizedaxoneme and fibrous sheath. However, most sections appear deformed and degenerated (d). Some sections show vacuolated mitochondria $(\mathrm{m})$ within mitochondrial sheath of middle piece (MP). (4E): Stress group showing aggregation of nuclear chromatin within nucleus of Leydig cell (asterisk). Its cytoplasm contains abundant dilated cisternae of smooth endoplasmic reticulum (arrow head).

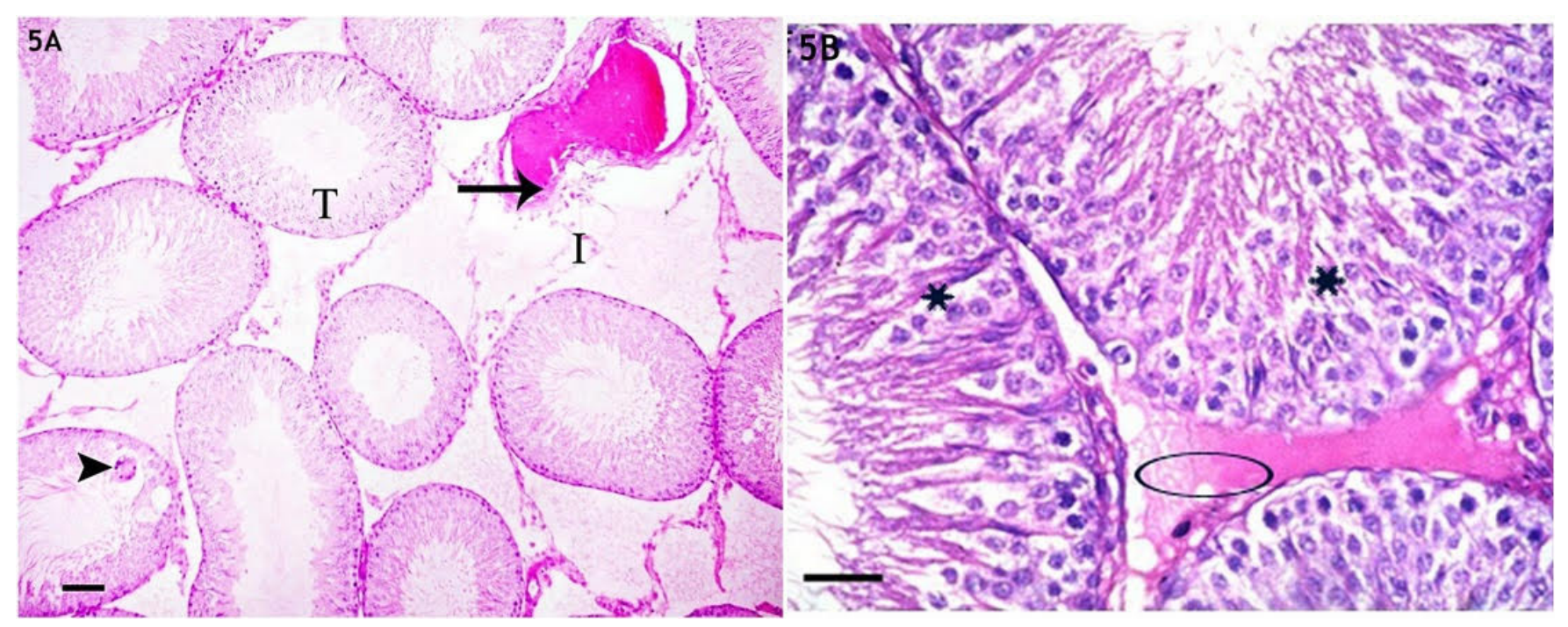

Fig. 5: A photomicrograph of a section in the testis ofprotectedgroup in adult albino rat: (5A): Protectedgroup showing most of seminiferous tubules (T) nearly have regular contour. Their epithelial lining exhibit multinucleated giant cells (arrowhead). The interstitiuminbetween (I) them is wide and contain congested blood vessels (arrow).(H\&E $\times 10$, scale bar $100 \mu \mathrm{m})$. (5B): Protectedgroup showing the linning epithelium of seminiferous tubule (T) have wide intercellular spaces between spermatogenic cells (stars). Interstitium contain homogenous acidophilic material (circle) $(\mathrm{H} \& \mathrm{E} \times 40, \mathrm{scale}$ bar $20 \mu \mathrm{m})$ 


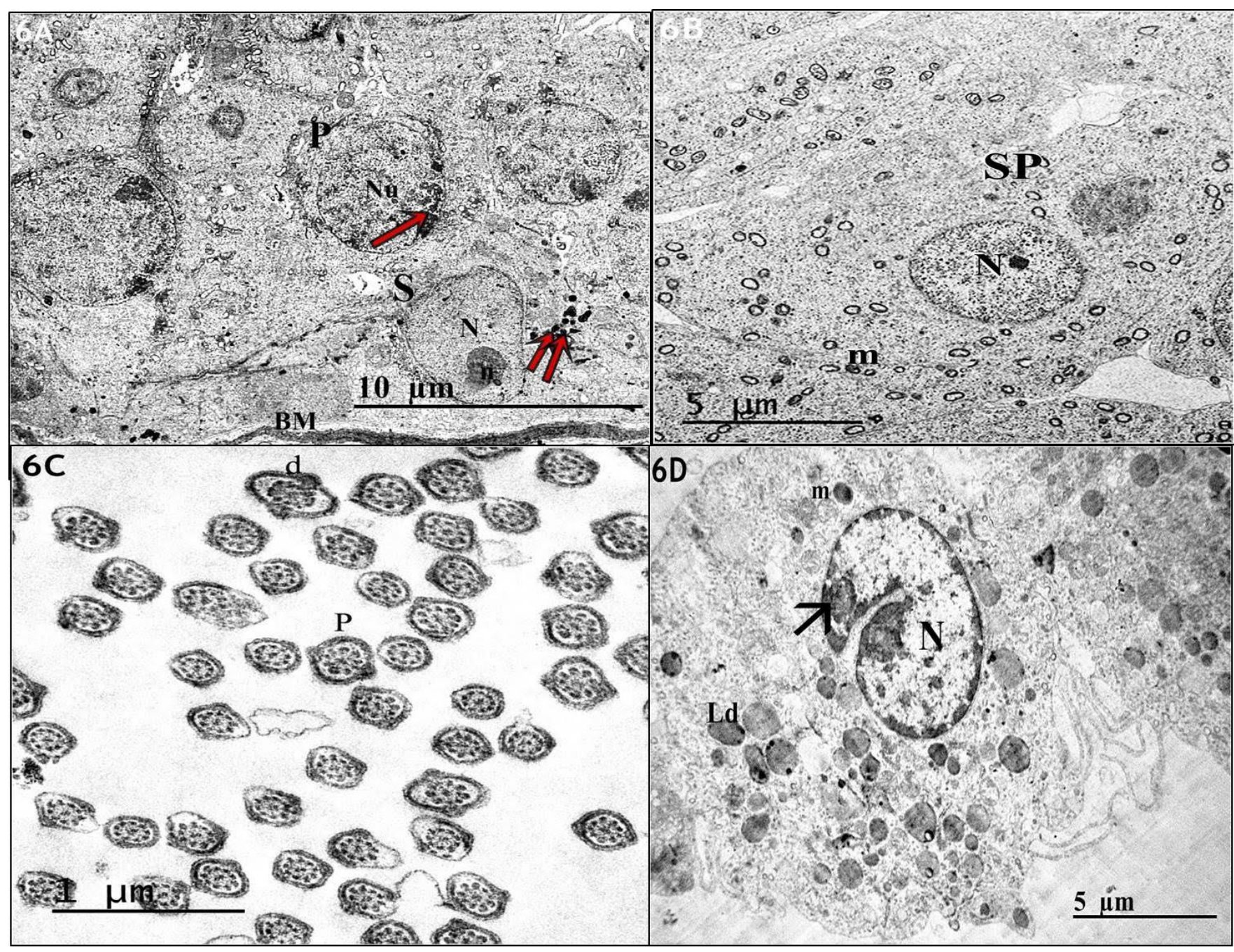

Fig. 6: Electron micrographs of ultrathin sections of albino rat's testis in protected group: (6A): Showingthat primary spermatocytes and Sertoli cell exhibit their normal fine structure. Primary spermatocytes (P) have large rounded nucleus $(\mathrm{Nu})$ with synaptonemal complex (red arrow). Sertoli cell (S) shows large euchromatic nucleus (N) with prominent nucleolus (n). However, some electron dense bodies (double red arrows) can be seen. They are resting on an irregular basement membrane (Bm). (6B): Showing a spermatid (SP) with large euchromatic nucleus (N). Its cytoplasm contains peripherally arranged mitochondria $(\mathrm{m})$. (6C): Showing that most transverse sections of sperms exhibit a normal appearance $(\mathrm{P})$ with well organizedaxoneme and fibrous sheath. However, few sperms appear deformed and degenerated (d). (6D): Showing a Leydig cell with irregular euchromatic nucleus (N) having coarse clumps of peripheral heterochromatin (arrow). Its cytoplasm contains lipid droplets (Ld) and mitochondria (m). 


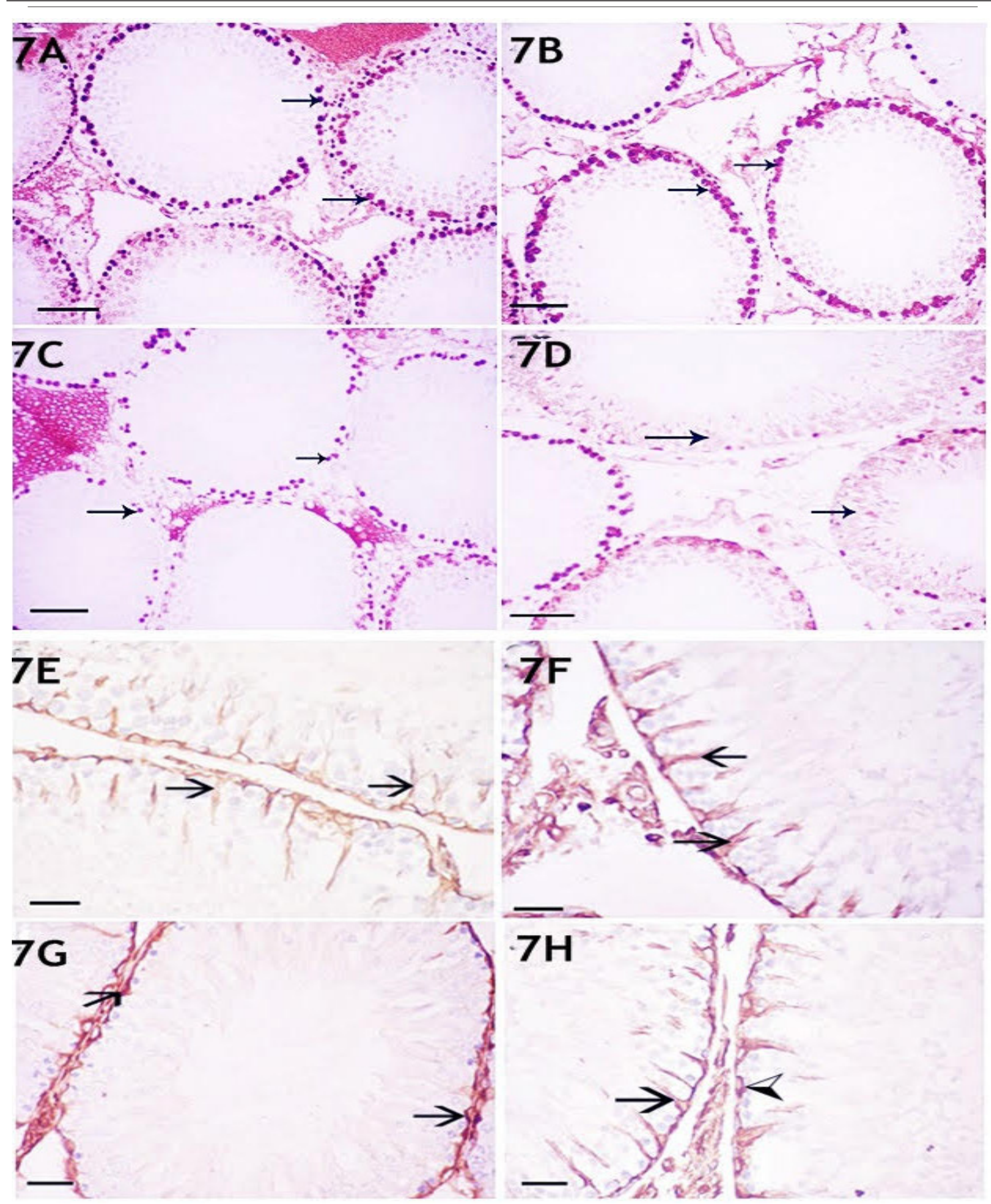

Fig. 7: A photomicrograph of immunohistochemical reaction: (7A): A section in the testis of a negative control rat (subgroup 1a) showing strong Ki 67 positive immunostaining in the spermatogenic cells. (7B): A section in the testis of a positive control rat (subgroup 1b) showing strong Ki 67 positive immunostaining in the spermatogenic cells. (7C): Stress group showing Ki 67 immunostaining in few spermatogenic cells. (7D): Protective group rat showing moderate immunostaining of $\mathrm{Ki} 67$ in spermatogenic cells. (Immunoperoxidase technique forKi-67×200, scale bar $100 \mu \mathrm{m})(7 \mathbf{E})$ : A section in the testis of a negative control rat (subgroup 1a) showing the distribution of vimentinimmunostaining (arrows) in the midportion and apices of Sertoli cells at their attachments to the germ cells and spermatozoa. (7F): A section in the testis of a positive control rat (subgroup 1b) showing the distribution of vimentinimmunostaining (arrows) in the midportion and apices of Sertoli cells at their attachments to the germ cells and spermatozoa. (7G): Stress group showing vimentinimmunostaining (arrows) present as streak in the midportion of Sertoli cells (7H): Protective group showing the distribution of vimentinimmunostaining in the midportion of some Sertoli cells (arrowhead) and others in apices of them (arrow)(Immunoperoxidase technique forvimentin $\times 400$, scale bar $20 \mu \mathrm{m})$ 
Mohammed et. al.

Table 1: Statistical results of the body weight percent $(\%)$ and relative weight of the testes $(\mathrm{g})$ in the studied groups

\begin{tabular}{|c|c|c|c|c|}
\hline Parameter & Control negative (Ia(Mean \pm SD & Control positive (Ib) Mean \pm SD & Stress (II) Mean \pm SD & Protective (III) Mean \pm SD \\
\hline (\%)gain in body weight $(\mathrm{g})$ & $31.16 \pm 2.06$ & $30.23 \pm 2.46$ & $6.19 \pm 5.05^{\mathrm{a}, \mathrm{b}}$ & $22.48 \pm 5.6^{\mathrm{b}, \mathrm{c}}$ \\
\hline Relative weight of the testes ( $\mathrm{g}$ ) & $1.137 \pm 0.016$ & $1.105 \pm 0.033$ & $0.661 \pm 0.028^{\mathrm{a}, \mathrm{b}}$ & $1.258 \pm 0.043^{\mathrm{b}, \mathrm{c}}$ \\
\hline
\end{tabular}

Data are presented as the mean \pm standard deviation

a significant compared to control negative group $(\mathrm{p}<0.05)$

b significant compared to control positive group $(\mathrm{p}<0.05)$

c significant compared to stress group $(\mathrm{p}<0.05)$

Table 2: Comparison between the studied groups regarding the sperm counts $(106 / \mathrm{mm} 3)$ and motility (\%):

\begin{tabular}{|c|c|c|c|c|}
\hline Parameter & Control negative (Ia) Mean \pm SD & Control positive (Ib) Mean \pm SD & Stress (II) Mean \pm SD & Protected (III) Mean \pm SD \\
\hline Testesterone (ng/ml) & $7.6 \pm .0234$ & $7.25 \pm 1.18$ & $3.680 \pm 0.265$ & $6.96 \pm 0.207$ \\
\hline Sperm count $\left(10^{6} / \mathrm{ml}\right)$ & $6.39 \pm 0.98$ & $6.11 \pm 0.23$ & $4.65 \pm 0.12^{\mathrm{a}, \mathrm{b}}$ & $5.5 \pm 1.36^{\mathrm{b}, \mathrm{c}}$ \\
\hline Sperm motility (\%) & $79.0 \pm 3.3$ & $78.4 \pm 3.2$ & $66.67 \pm 5.77^{\mathrm{a}, \mathrm{b}}$ & $70.3 \pm 1.2^{\mathrm{b}, \mathrm{c}}$ \\
\hline
\end{tabular}

Data are presented as the mean \pm standard deviation

a significant compared to control negative group $(\mathrm{p}<0.05)$

$\mathrm{b}$ significant compared to control positive group $(\mathrm{p}<0.05)$

c significant compared to stress group $(\mathrm{p}<0.05)$

Table 3: Statistical results of the morphmetrical results in studied groups

\begin{tabular}{|c|c|c|c|c|}
\hline Parameter & Control negative (Ia) Mean \pm SD & Control positive (Ib) Mean \pm SD & Stress (II) Mean \pm SD & Protective (III) Mean \pm SD \\
\hline $\begin{array}{l}\text { main diagonal diameter } \\
\text { of seminiferous tubules }\end{array}$ & $190.9 \pm 75.6$ & $188.5 \pm 33.2$ & $104.2 \pm 5.9^{\mathrm{a}, \mathrm{b}}$ & $126.5 \pm 5.9^{\mathrm{b}, \mathrm{c}}$ \\
\hline $\begin{array}{l}\text { main thickness of } \\
\text { testicular epithelium }\end{array}$ & $147.6 \pm 15.5$ & $150.3 \pm 12.1$ & $68.2 \pm 16.1^{\mathrm{a}, \mathrm{b}}$ & $135.8 \pm 20.9^{b, c}$ \\
\hline $\mathrm{Ki}-67$ (\% area) & $33.4 \pm 10.4$ & $30.9 \pm 2.5$ & $15.7 \pm 6.9^{\mathrm{a}, \mathrm{b}}$ & $25.9 \pm 9.9^{\mathrm{b}, \mathrm{c}}$ \\
\hline Vimentin (\% area) & $40.03 \pm 10.1$ & $39.11 \pm 6.2$ & $29.2 \pm 7.3^{\mathrm{a}, \mathrm{b}}$ & $38.1 \pm 9.01^{\mathrm{b}, \mathrm{c}}$ \\
\hline
\end{tabular}

Data are presented as the mean \pm standard deviation

a significant compared to control negative group $(\mathrm{p}<0.05)$

$\mathrm{b}$ significant compared to control positive group $(\mathrm{p}<0.05)$

c significant compared to stress group $(\mathrm{p}<0.05)$

Table 4: Testicular level of MDA and TAC in the studied groups.

\begin{tabular}{|c|c|c|c|c|}
\hline Parameter & Control negative (Ia) Mean \pm SD & Control positive (Ib) Mean \pm SD & Stress (II) Mean \pm SD & Protective (III) Mean \pm SD \\
\hline MDA(nmol/g tissue) & $0.166 \pm 5.11$ & $0.133^{\mathrm{a}} \pm 4.92$ & $15.23 \pm 0.206^{\mathrm{a}, \mathrm{b}}$ & $5.27 \pm 0.24^{\mathrm{b}, \mathrm{c}}$ \\
\hline $\mathrm{TAC}(\mathrm{nmol} / \mathrm{g}$ tissue & $0.802 \pm 0.207$ & $1.122 \pm 0.217^{\mathrm{a}}$ & $0.564 \pm 0.125^{\mathrm{a}, \mathrm{b}}$ & $0.728 \pm 0.132^{\mathrm{b}, \mathrm{c}}$ \\
\hline
\end{tabular}

MDA: malondialdehydeTAC: total antioxidant capacity

a significant compared to control negative group $(\mathrm{p}<0.05)$

b significant compared to control positive group $(p<0.05)$

c significant compared to stress group $(\mathrm{p}<0.05)$ 


\section{DISCUSSION}

Chronic stress is a major risk factor for several human complaints that affect modern societies. In the present work, serum testosterone levels decreased in rats subjected to stress stimuli. The same data were obtained by Lin et al. ${ }^{[27]}$ who stated that chronic stress increases glucocorticoid levels thereby suppressing the release of gonadotropins and acting directly on Leydig cell receptors, inhibiting testosterone biosynthesis.

In the current work, we observed that the relative testicular weights of rats in the stress group decreased significantly when compared with the control group. The same data were obtained byGarcía-Díaz et al. ${ }^{[28]}$ who noticed decreased the weight in rats stressed for 50 consecutive days and considered that an important parameter to assess the risk of toxic effects in the male reproductive system.

Additionally, this work showed a significant decrease in total sperm count and motility in stress group when compared with control group. The same data were obtained by Bitgul et al. ${ }^{[29]}$; Nirupama and Yajurvedi ${ }^{[15]}$ and Hou et al. ${ }^{[30]}$ who stated that chronic stress causes decrease in serum testosterone levels. It is known that testosterone deprivation decrease both motility and fertilizing capacity and cause sperm death.

As regards the microscopic results of testes of stress group, the seminiferous tubules showed exfoliated germ cells with appearance of many vacuoles within germinal epithelium. Elshaari et al. ${ }^{[31]}$ suggested that these sloughed germ cells may be spermatocytes and/or spermatids. On the other hand, Creasy et al. ${ }^{[32]}$ attributed the exfoliation of the germ cells to loss of its contact with the cytoplasmic processes of the surrounding Sertolicells.Also, a significant reduction in the height of germinal epithelial lining seminiferous tubules was noticed when compared with the control group. Similar findings were observed by Elshaari et al. ${ }^{[31]}$ who attributed these changes to the occurrence of oxidative stress.

In the present study, wide interstitium contained homogenous acidophilic material was noticed. It may be due to an increase in vascular permeability ${ }^{[33]}$.

Vimentin is an intermediate filament protein expressed in Sertoli cells providing them structural and functional support. So, the study of vimentin expression could be useful to understand the changes in Sertoli cells ${ }^{[34]}$. In the current study, statistical analysis of the results showed a significant decrease in area \% of Vimentin of stress group when compared with control group. Similar results were previously described by Chen et al. ${ }^{[35]}$ and Reda et al. ${ }^{[34]}$ who suggested that oxidative stress may reduce vimentin filaments in the testis.

Electron microscopic results showed Sertoli cell with an irregular nuclear envelope, many cytoplasmic vacuoles and dilated SER.These findings were in accordance withAgarwal et al. ${ }^{[33]}$ who reported that oxidative stress led to appearance of cytoplasmic vacuolations in Sertoli cells. Also, Levine et al. ${ }^{[36]}$ attributed the appearance of cytoplasmic vacuolations to the hydropic degeneration resulting from mitochondrial dysfunction and disruption of sodium pump with increased sodium influx and attraction of water. Also, multiple electron dense bodies with variable sizes and lysosomes were noticed in cytoplasm of Sertolicell in the stress group. This was in accordance with Zhang et al. ${ }^{[37]}$ who reported that stress can induce activation of autophagy in the testicular cells.

In the present work, some sloughed spermatids with eccentric irregular shrunken pyknotic nuclei were noticed. Similar findings were observed by Reda et al. ${ }^{[34]}$. Also, some sperms appeared deformed and degenerated with vacuolated mitochondria. Similar findings were found byRibeiro et al. ${ }^{[38]}$ in rats subjected to chronic stress stimuli in adulthood.

The effects of stress on the activity of total antioxidant capacityand malondialdehyde(MDA) have been examined. Our result revealed that there is decrease in the level of antioxidant in the testes of rats subjected to chronic stress while the level of MDA increases which reflected lipid peroxidation and damage to plasma membrane as a consequence of oxidative stress.Chronic stress has been associated with altering antioxidant enzyme activity and oxidative damage to membrane lipids and DNA in testes ${ }^{[39]}$. These alterations are explained by the negative effects of ROS, such as hydrogen peroxide $\left(\mathrm{H}_{2} \mathrm{O}_{2}\right)$ and hydroxyl radical (HO-). Both germ cells and sperm are vulnerable to oxidative stress because they contain high levels of long chain and very long chain highly unsaturated fatty acids, susceptible of being oxidized and cause cellular damage.Stressors are known to increase ROS production and excessive ROS production can overwhelm antioxidant defense strategies $^{[40]}$.

Barros et al. ${ }^{[41]}$ reported thatdifferent antioxidant enzymes, SOD, GPx, and GST scavenge free radicals and form the major antioxidant system. These factors had been evaluated in our studywhichshowed attenuation in the mRNA expression of SOD and GST and GPx in testes of rats subjected to chronic stress. While the levelsof those enzymes were preserved in astaxanthin(AST) protected group, and this may 
potentiate that AST exerts potential effects against oxidative stress and may inhibit the production of free radicals and up regulate the expression of antioxidant enzymes.

The antioxidant property of AST is about 10 -fold greater than those of other carotenoids, including luteinand $\beta$ carotene andis $100-1000$ times greater than that of vitamin $E^{[42]}$. Experimental studies confirm that this nutrient has a large capacity to neutralize free radicals or other oxidant activity in the nonpolar (hydrophobic) zones of phospholipid aggregates, as well as along their polar (hydrophilic) boundary zones ${ }^{[43]}$.

Stress inducedLeydig cells apoptosis resulting in alteration of steroidogenic activity of the testis and reduced testosterone secretion ${ }^{[44]}$. We evaluate apoptotic effect of chronic stress by estimation of the activity of caspase 3, a marker for apoptosis, Ki-67 nuclear immunoreactivityand mRNA expression ofKi-67; marker of cell proliferation. Immunoreactivity to $\mathrm{Ki}-67$ was observed infew spermatogenic cellsof stress group while protective group revealed moderate nuclear immunoreactivity to the same proteins. The same results obtained by Alkhedaide et al. ${ }^{[7]}$ who mentioned that the expression of $\mathrm{Ki}-67$ is a mechanism by which the body can resist the degenerative effects which occur in the testes.High expression of $\mathrm{Ki}-67$ has been reported in cells during G2 and early $M$ stages of cell growth. Our result also revealed that level of caspase 3 markedly increase in the testes of stressed rat. Also histological examination of Leydig cells showed that those cells appeared with aggregated nuclear chromatin. Its cytoplasm contains abundant dilated cisternae of smooth endoplasmic reticulum which reflected apoptotic picture.

\section{CONCLUSION}

In conclusion, the present study demonstrates that stress can cause imbalance in oxidant-antioxidant system and has apoptotic effect leading to testicular damage.

Also, astaxanthin showed beneficial effects in reduction of stress-induced testicular oxidative stress, apoptosis, suppression of testicular germ and Sertoli cells, Leydig cell dysfunction as well as abnormal testicular histopathology. These may be through inhibiting lipid peroxidation and enhancing antioxidant defense systems in rats. Therefore, astaxanthin may be a suitable nutritional supplement in alleviating some negative aspects of chronic stress effects on spermatozoa that deserves further molecular examination.

\section{CONFLICT OF INTEREST}

There is no potential conflict of interest among the authors

\section{ETHICAL APPROVAL}

The study was carried out according to the guidelines of the ethical committee of the faculty of medicine, Zagazig University

\section{REFEREANCES}

1. Eisenmann ED, Rorabaugh BR, ZoladzPR. Acute stress decreases but chronic stress increases myocardial sensitivity to ischemic injury in rodents. Front psychiatry2016; 7( 1):71.

2. Koolhaas JM, Bartolomucci A, Buwalda B, de Boer S.F, Flugge G, Korte SM. Stress revisited: A critical evaluation of the stress concept. NeurosciBiobehav Rev 2011; 35:1291-1301.

3. DimsdaleJE.Psychological stress and cardiovascular disease. JAm CollCardiol 2008; 51(13): 1237.1246-

4. Reber SO, Slattery DA.Using stress-based animal models to understand the mechanisms underlying psychiatric and somatic disorders. Front psychiatry 2016; 7: 192.

5. Lagraauw HM, Kuiper J, Bot I.Acute and chronic psychological stress as risk factors for cardiovascular disease: Insights gained from epidemiological, clinical and experimental studies. Brain BehavImmun 2015; 50: 1830-.

6. Meijer OC.Understanding stress through the genome. Stress 2006; 9(2): 6167-.

7. Alkhedaide A, Alshehri ZS, Sabry A, Abdel-Ghaffar T, Soliman MM, Attia H. Protective effect of grape seed extract against cadmium-induced testicular dysfunction. Mol Med Rep 2016; 13: 31013109-.

8. Cuylen S, Blaukopf C, Politi AZ, Müller-Reichert T, Neumann B, Poser I, Ellenberg J, Hyman AA, Gerlich DW.Ki-67 acts as a biological surfactant to disperse mitotic chromosomes. Nature 2016; 535 (7611): 308-12.

9. Elmasry SA,Al-Azzaw MA, Ghoneim AH, Nasr MY, AboZaid MMN. Role of oxidant-antioxidant imbalance in the pathogenesis of chronic obstructive pulmonary disease.Egyptian Journal of Chest Diseases and Tuberculosis 2015;64 (4): 813820- 
10. Turner TT, Lysiak JJ. Oxidative stress: a common factor in testicular dysfunction. J Androl2008; 29(5):488-498.

11. Li X, Qi Z, Zhao L, Yu Z. Astaxanthin reduces type 2 diabetic associated cognitive decline in rats via activation of $\mathrm{PI} 3 \mathrm{~K} / \mathrm{Akt}$ and attenuation of oxidative stress. Mol med reports 2016; 13(1): 973.979-

12. Mortazavi M, Salehi I, Alizadeh Z, Vahabian M, AmanehRoushandehM.Protective Effects of Antioxidants on Sperm Parameters and Seminiferous Tubules Epithelium in High Fat-fed Rats. J ReprodInfertil2014; 15(1): $22-28$

13. RoushandehAM, Salehi, Mortazavi M. Protective Effects of Restricted Diet and Antioxidants on Testis Tissue in Rats Fed with High-Fat Diet. Iran Biomed J2015; 19(2): 96-101.

14. Dokumacioglu E, Iskender H, Yenice G, Kapakin KAT, Sevim C, Hayirli A, Saral S, Comakli S. Effects of astaxanthin on biochemical and histopathological parameters related to oxidative stress on testes of rats on high fructose regime. Andrologia2018; 50 (7): 13042.

15. Nirupama M, Yajurvedi HN.Durational effects of chronic stress on the testicular damage and its reversibility in albino rat. Euro J Exp Bio 2013; 3(5): 229239-

16. Akca G, Eren H, Tumkaya L, Mercantepe T, Horsanali MO, Deveci E, Yilmaz A. The protective effect of astaxanthin against cisplatin-induced nephrotoxicity in rats. Biomed Pharmacother 2018; 100: 575582-.

17. Wheelan N, Kenyon CJ, Harris AP, Cairns C, Al Dujaili E, Seckl J R, Yau J L. Midlife stress alters memory and mood-related behaviors in old age: Role of locally activated glucocorticoids. Psychoneuroendocrinol2018; 89: 1322-.

18. Bancroft JD, Layton C.The Hematoxylin and eosin. In: Suvarna SK, Layton C and Bancroft JD editors. Theory and Practice of histological techniques.7th ed., Churchill Livingstone of El Sevier Philadelphia; 2017.172214-.

19. Kiernan JA. Histological and HistochemicalMethods. Theory and Practice, 4th ed., Butterworth Heinemann, Oxford, Boston; 2008.
20. Hayat M. Principles and Techniques of Electron Microscopy Biological Applications. 4th ed., Mac Millan Press, London; 2000.7092.

21. Jensen EC. Quantitative Analysis of Histological Staining and Fluorescence Using Image. J Anat Rec2013; 296: 378-381.

22. Novelli E, Diniz Y, Galhardi C, Ebaid G, Rodrigues H, Mani F, Fernandes A, Cicogna A, Novelli FJ. Anthropometrical parameters and markers of obesity in rats. Laboratory Animal 2007; 41(1): 111119-.

23. Dygalo NN, Shemenkova TV, Kalinina TS, Shishkina GT. A critical point of male gonad development: neuroendocrine correlates of accelerated testicular growth in rats during early life. PloS ONE 2014; 9(4): 1.8-

24. Gholib G, Wahyuni S, Kadar OH, Adam M, Lubis TM, Azhar A, Akmal M, Siregar TN, Armansyah T, Nugraha TP. Measurment of serum testosterone in kacang goat by using enzyme-linked immunosorbent assay (ELISA) technique: the importance of kit validation (PengukuranTestosteron Serum KambingKacangdenganTeknik Enzyme-Linked Immunosorbent Assay (ELISA): PentingnyaValidasi Kit). J KedokteranHewan2016; 10(1): 3236-.

25. Mesbah S, Shokri S, Karbalay-Doust S, MirkhaniH.Theeffectofnandrolonedecanoate on the body, testis and epididymis weightand semen parameters in adult male rats.Iran $\mathrm{J}$ Medical Sci2007; 32: 93-99.

26. Cheng D, Zheng XM, Li SW, Yang ZW, $\mathrm{Hu}$ LQ. Effects of epidermal growth factor on sperm content and motility of rats with surgically induced varicoceles. Asian J Androl 2006; 8: 713-717.

27. Lin $\mathrm{H}$, Yuan KM, Zhou HY, Bu T, Su H. Time-course changes of steroidogenic gene expression and steroidogenesis of rat Leydig cells after acute immobilization stress. Int J MolSci2014; 15 (11): 2102821044-.

28. García-Díaz EC, Gómez-Quiroz LE, ArenasRíos E, Aragón-Martínez A, Ibarra-Arias JA, Retana-Márquez MA. Oxidative status in testis and epididymalspermparameters after acute and chronic stress by coldwater immersion in the adult rat.SystBiolReprod Med 2015; 61(3): 150-160. 
29. Bitgul G, Tekmen I, Keles D, Oktay G. Protective effects of resveratrol against chronic immobilization stress on testis. ISRN Urol2013; 2013: 278720 .

30. Hou G, Xiong W, Chen X, Yuan TF.Chronicstressinfluences sexual motivation and causes damage to testicularcells in male rats. J Sex Med 2014; 11:653-63.

31. Elshaari FA, Elfagih RI, Sheriff DS, Barassi IF. Testicular torsion/detorsion. Histological and Biochemical Changes in Rat Testis. J CytolHistol 2012; 3: 99115-

32. Creasy D, Bube A, de Rijk E, Kandori H, Kuwahara M, Masson R, Nolte T, Reams R, Regan K, Rehm S, Rogerson P, Whitney K. Proliferative and non proliferative lesions of the rat and mouse male reproductive system. ToxicolPathol 2012; 40: 40121-

33. Agarwal A, Virk G, Ong C, du Plessis SS. Effect of Oxidative Stress on Male Reproduction. World J Mens Health 2014; 32: 117-.

34. Reda SM, Hashem HE, Elnegris HM, ElshalLM. Role of bone marrow derived mesenchymal stem cells in protection of spermatogenic and Sertoli cells against histological alterations induced by torsion/ detorsion in rats. J Med Histo 2018; 1(2): 25369172-.

35. Chen Y, Gang L, Yeyong Q, Ming C, Hong Y, Lixiao W, Fengjie, G, Bingyi S. Protection of Pentoxifylline against Testis Injury Induced by Intermittent Hypobaric Hypoxia. Oxid Med Cell 2016; 10: 268275 -

36. Levine S, Saltzman A,Ginsberg SD. Vacuolar pathology in the median eminence of the hypothalamus after hyponatremia. J NeuropatholExpNeurol2011; 70: 115126-.
37. Zhang M, Jiang M, Bi Y, Zhu H, Zhou Z. Autophagy and apoptosis act as partern to induce germ cell death after heat stress in mice. Plos One 2012; 7 (7): e41412.

38. Ribeiro CT, De Souza DB, Costa WS, Sampaio FJB, Pereira-SampaioMA. Immediate and late effects of chronic stress in the testes of prepubertal and adult rats. Asian J Androl 2018; 20: 385-390

39. Nirupama $M$, Devaki $M$, Nirupama $R$, Yajurvedi HN. Chronic intermittent stressinduced alterations in thespermatogenesisand antioxidant status of the testis are irreversible in albino rat. J PhysiolBiochem2013; 69:5968.

40. Parodi J. Motility, viability, and calcium in the sperm cells. SystBiolReprod Med 2014; 60: 65-71.

41. Barros MP, Poppe SC, BondanEF. Neuroprotective properties of the marine carotenoid astaxanthin and omega-3 fatty acids, and perspectives for the natural combination of both in krill oil. Nutrients2014; 6(3): 1293-1317.

42. Wang JY, Lee YJ, Chou MC, Chang R, Chiu $\mathrm{CH}$, Liang YJ, Wu LS. Astaxanthin Protects Steroidogenesis from Hydrogen PeroxideInduced Oxidative Stress in Mouse Leydig Cells. Marine Drugs, 2015; 13(3):137588-.

43. Hussein MA. Cardioprotective Effects of astaxanthin against isoproterenol-induce cardiotoxicity in rats. J Nutr Food Sci 2014; 5(1): 335-340.

44. Whirledg S, Cidlowski JA.Glucocorticoids, stress and fertility.Minerva Endocrinol2010; 35(2):109125-. 
الملخص العربى

تأثثر الإجهاد المزمن على خصية الجرذان البيضاء البالغة والتأثير الوقائىالمحتمل للامد اد بالأستاز انتين (در استة هستولوجية ولهية وهنتوكميائية مناعية وكيميائية حيوية)

\author{
مهاز ايد محمد حسن 1 وكريمة فوزي عبد الفضيل1 وهبة عبد العزيز1 \\ و أمل فوزي و و لاء سامي² \\ 1قسم الههتولوجيا وبيولوجيا الخلية ـ كلية الطب - جامعه الزقازيق ولاءيق \\ 2قسم الكيمياء الحيوية ــ كلية الطب - جامعه الزقازيق
}

المقدمة والأهداف: يمكن للإجهاد أن يعطل التوازن التماتلي في الكائنات الحية. يمكن أن يكون للإجهاد المزمن آثار ضارة على الكائن ككل. هدفت الدر اسة الحالية إلى إلقاء المزيد من الضو ء على التغير ات الجزيئية و المناعية و النسيجية في خصية الجرذان البيضاء الخاضعة للضغط النفسي المزمن و لإثبات ما إذا كان حدوث تغير ات الخصية الناجمة عن الإجهاد المزمن يمكن تحسينه بو اسطة أستاز انتين أم لا.

مواد وطرق البحث: استخدم في هذه الدراسة أربعين من ذكور الجرذان البيضاء البالغة ، وتم تقسيمهم الي ثلاث مجمو عات رئيسية : المجمو عة الأولى (مجمو عة الضابطة) التي تم تقسيمها الي مجمو عتين فرعيتين ، المجمو عة الثانية (مجمو عة الضغط) تم تقييد الفئر ان لمدة ساعة و احدة وبعد فترة4 ساعات أجبرت على السباحة لمدة 15 دقبقة يوميا لمدة 6 أثنهر ومجموعة III (مجموعة الحماية) تعرضت الجرذان لضغوط كما المجموعة الثانية في ما يصاحب ذللك تتاول الاستاكسنسين يوميا بجرعة 25 مجم لكل كيلو جر ام من وزن الجسم مذاب في 1 مليلتر محلول ملحي في جرعة يومية و احدةعن طريق الفم ـ وقد تم جمع الأنسجة الخلوية من الخصية و عينات الدم لدر اسة التغير ات الهستولوجية و المناعية و الكيميائية الحيوية. النتائج: وقد أثنتت نتائج الدر اسة الحالية على مستوى الأنسجة لوحظو جود تغير ات تحليليه في الخلايا المولدة للنطاف وخلايا الدعم و التي كانت مصحوبة بانخفاض ذو دلالة احصائية في ارتفاع النسيج الطلائي الجرثومي و النسبة المئويى للتعبير المناعي الهستوكيميائي لل Ki-67 و vimentin وقد لوحظ تر اجع هذه التغير ات في المجموعة التي تتاولت أستاز انتين.كما أن هناك انخفاض في مستويات هرمون التستوستيرون في الدم في مجموعة الضغط ، و التي اصبحت قريبة من الطبيعي بعد تتاول الأستاز انتين. أيضازيادة كبيرة في مستويات المالوندايالدهيد ، و انخفاض مستويات القدرة

الكلية المضادة للاكسدة.

الاستتتاج: وخلصت هذه الدر اسة إلى أن الأستاز انتين له آثار وقائية مفيدة ضد الآثار الضارة للإجهاد على الخصية. لذلك ، قد يكون مكمل غذائي مناسب في التخفيف من بعض الجو انب السلبية للاجهاد المزمن على الخصية. 